\title{
Talouden tarttuvat tarinataudit
}

Niklas Jensen-Eriksen

Robert J. Shiller: Narrative Economics: How Stories

Go Viral \& Drive Major Economic Events. Princeton

University Press 2019.

ISBN 9780691182292.

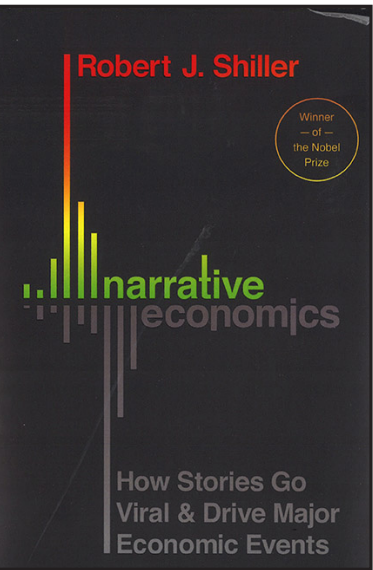

Tarinat leviävät kuin taudit, kertoo Nobel-palkittu taloustieteilijä Robert J. Shiller kirjassaan Narrative Economics. Tarinoiden sijasta olisi tosin oikeampaa puhua suomeksi kertomuksista, sanomasta tai narratiiveista, sillä Shillerin mukaan "narrative" on tarina (story), jonka avulla halutaan vakuuttaa lukija jostain tai välittää hänelle tietynkaltainen näkemys. Tarinoijat haluavatkin usein myydä tai markkinoida jotain, pahimmillaan huijata.

Shillerin kirja julkaistiin ennen koronakriisin alkua, mutta tuskin kukaan voi lukea sitä keväällä ja kesällä 2020 ajattelematta covid-19-pandemiaa. Kirja nimittäin vilisee koronakevään uutisoinnista tuttuja ilmauksia. Tarinavirukset muuttuvat, ja jotkut mutaatiot ovat erityisen tarttuvia. "Supertartuttajat" levittävät tauteja erityisen laajalle, mutta muuten on suurelta osin epäselvää, miksi jotkut sairastuvat ja toiset taas eivät. Ja lopulta tarina katoaa, mutta saattaa palata takaisin hieman eri muodossa. Shiller uskookin, että epidemiologisten mallien ja käsitteiden avulla voidaan tutkia myös tarinoiden leviämistä.

Totuudenmukaisuus ei ole edellytys tarinan leviämiselle. Perättömät kertomukset leviävät nopeammin, koska ihmiset haluavat yllättää toisensa. Alkuperäkin vääristyy helposti: Bostonin pormestarin avustaja Thomas Mullen totesi vuonna 1931, että ei ole muuta pelättävää kuin pelko itse. Pari vuotta myöhemmin saman totesi presidentti Franklin D. Roosevelt virkaanastujaispuheessaan, ja siitä lähtien hän onkin saanut kunnian ajatuksesta. Tunnettu ihminen saa helpommin tarinansa leviämään.

Sanamuodoillakin on väliä: James Truslow Adamsin vuonna 1931 lanseeraamasta käsitteestä "American dream" tuli viraali-ilmiö, kun taas vähemmän iskevistä "American character", "American principles" ja "American credo" ei tullut. "Amerikkalainen unelma" ei kuvannut vain maan luonnetta, vaan ilmaisuun sisältyi haave paremmasta. Käsitteen etuna oli myös muokattavuus: taitavat puhujat, kuten Martin Luther King, Jr. saattoivat tarjota oman, kuulijoita puhuttelevan versionsa unelmasta.

Shiller ei kerro tarinoista tarinoimisen ilosta, vaan siksi että ne vaikuttavat talouteen, politiikkaan ja muuhun yhteiskuntaan. Tämä on tiedostettu monella tieteenalalla, kuten kirjallisuudentutkimuksessa, uskontotieteessä, antropologiassa ja historiassa, mutta ilmiö ei ole erityisemmin kiinnostanut taloustietelijöitä. He ovat vierastaneet aiheita, joita on vaikea tutkia eksaktien tilastollisten menetelmien avulla. "Not our field", taloustietelijät vastaavat Shillerin mukaan ja kehottavat kääntymään vaikkapa mediatutkijoiden tai sosiologien puoleen. Näiden alojen tutkijat taas eivät useinkaan tunne yksityiskohtaisesti talouden maailmaa, mikä jättää sen tarinat ei-kenenkään-maalle. 
Talouselämä ei ole kuitenkaan immuuni tarinataudeille. Kiinteistökuplat kasvavat, kun ihmiset muistuttavat toisilleen, ettei maata tehdä lisää. Industrialismin alkuvaiheista lähtien on myös kerrottu, että juuri omana aikana ollaan suuren teknologisen harppauksen kynnyksellä, ja pian moni on työtön ja tarpeeton. Pörssisijoittajat kertovat tarinoita voitoista ja tappioista ja vertaavat oman aikansa kurssikehitystä 1920-luvun nousuun, 1930-luvun laskuun tai johonkin muuhun vaiheeseen - tietämättä todellisuudessa miten kurssit tulevat kehittymään. Näin on käynyt kevään 2020 pörssiheilunnankin aikana.

Hyvänä tarinankertojana Shillerillä on silmää iskeville anekdooteille. 1930-luvun suuren laman aikana Yhdysvalloissa oltiin huolissaan siitä, miten automatisointi tappaa käsivälitteisissä puhelinkeskuksissa ahkeroivien työpaikat. Ja vieläpä aikana, jolloin työttömyys kasvoi nopeasti. Liittovaltion senaatti teki vuonna 1930 päätöksen poistaa "iljettävät" (abominable) modernit puhelimet tiloistaan. Aloitteen tehnyt senaattori Carter Glass julisti, että hän kieltäytyy muuttumasta puhelinyhdistyksen työntekijäksi ilman korvausta. Shiller ei kerro, miten tarina jatkuu, mutta lukija arvaa, että senaatin päätös ei jäänyt pysyväksi.

Tarinoiden tutkijalle tekniikan kehitys on etu, sillä digitalisointi on tuonut entistä paremmat mahdollisuudet jäljittää narratiivien leviämistä. Shiller on hyödyntänyt menestyksellä Google Ngrams ja ProQuest News \& Newspapers -palveluita jäljittäessään tarinoiden leviämisestä kertovia sanoja ja sanaryhmiä.

Shillerin lähestymistavan ongelmana on epämääräisyys. Kirja on täynnä mainiota tarinoita, mutta välillä lukijalle tulee epäilys, että pitäisikö narratiivien sijasta puhua vaikkapa muoti-ilmiöistä, ihanteista tai vain yleisesti käyttäytymisestä. Esimerkiksi 1930-laman aikana Yhdysvalloissa henkilöautojen myynti romahti, eivätkä edes varakkuutensa säilyttäneet ihmiset ostaneet niitä. Polkupyöräily lisääntyi, ja yhä useampi mielsi sen lama-aikaan sopivaksi liikkumismuodoksi. Kuluttamista ja erityisesti rikkauden näyttämistä paheksuttiin herkästi maassa, jossa monet kärsivät. Ihmiset sopeutuivat muuttuvaan yhteiskunnalliseen ilmapiiriin - ja kiihdyttivät samalla talouden syöksykierrettä.

Kaikki ei ole tarinointia, mutta Shiller osoittaa silti vakuuttavasti, että talouden tutkijoidenkin pitäisi kartoittaa enemmän narratiiveja. Digitalisointi tarjoaa siihen entistä tehokkaampia työkaluja. 